Pengukuran Kemampuan Pemahaman....(Irsyadatul Mahmudah)

\title{
PENGUKURAN KEMAMPUAN PEMAHAMAN KONSEP MATEMATIKA MELALUI IMPLEMENTASI MODEL PEMBELAJARAN KNISLEY BERBASIS GAYA BELAJAR
}

\author{
Oleh: Irsyadatul Mahmudah', Siti Munawarroh², Ainur Rosikin³, \\ Abdul Halim Fathani ${ }^{4}$ \\ (Dosen Universitas Islam Malang)

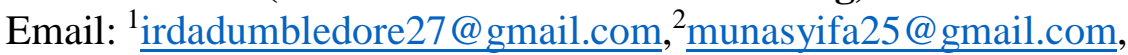 \\ 3ainurrosikin190@gmail.com, ${ }^{4}$ fathani@unisma.ac.id
}

\begin{abstract}
Abstrak
Tujuan penelitian ini untuk mengetahui ada atau tidaknya perbedaan yang signifikan antara kemampuan pemahaman konsep siswa yang mengikuti model pembelajaran matematika Knisley (MPMK) berdasarkan gaya belajar dengan kemampuan pemahaman konsep siswa yang mengikuti pembelajaran konvensional, serta mendeskripsikan kemampuan pemahaman konsep siswa yang mengikuti model pembelajaran matematika Knisley (MPMK) berdasarkan gaya belajar dan kemampuan pemahaman konsep siswa yang mengikuti pembelajaran konvensional. Penelitian ini dilakukan di SMP Islam 01 Batu, Kelas VII pada materi segiempat dengan sampel 23 siswa sebagai kelas eksperimen dan 23 siswa kelas kontrol. Analisis data dalam penelitian ini adalah dengan menggunakan uji normalitas, uji homogenitas dan uji two-way ANOVA. Berdasarkan hasil analisis data penelitian kuantitatif menunjukkan bahwa terdapat perbedaan antara kemampuan pemahaman berdasarkan gaya belajar antara siswa yang mengikuti model pembelajaran matematika Knisley (MPMK) dengan siswa yang mengikuti model pembelajaran konvensional. Sedangkan hasil data penelitian kualitatif diperoleh kemampuan pemahaman konsep berdasarkan gaya belajar auditorial untuksiswa yang mengikuti model pembelajaran matematika Knisley (MPMK) lebih baik dibandingkan kemampuan pemahaman konsep berdasarkan gaya belajar visual dan kinestetik.
\end{abstract}

Kata Kunci : Pemahaman Konsep Matematika, Model Pembelajaran Knisley, Gaya Belajar

\section{MEASUREMENT OF ABILITY OF CONCEPTUAL UNDERSTANDING IN MATHEMATICS THROUGH THE IMPLEMENTATION OF KNISLEY LEARNING MODEL BASED ON LEARNING STYLES}

\begin{abstract}
This research is motivated by the low ability of understanding the concept of students and the use of the model given by the teacher is still less effective because the applied learning model is still centered on the teacher that is conventional learning. The purpose of this study is to determine whether or not there is a significant difference between the ability to understand the concepts of students who follow the model of learning mathematics Knisley based on learning styles with the ability to understand the
\end{abstract}


concept of students who follow conventional learning, and describes the ability to understand the concept of students who follow the model of learning mathematics Knisley based on learning styles and students' conceptual understanding abilities that follow conventional learning. This research was conducted in Islamic Junior High School 01 Batu, Class VII in quadrilateral material with sample of 23 students as experiment class and 23 students of control class. Data analysis in this research is by using normality test, homogeneity test and two-way ANOVA test. Based on the results of quantitative research data analysis shows that there is a difference between the ability of understanding based on learning styles between students who follow the model of learning mathematics Knisley with students who follow the conventional learning model. While the results of qualitative research data obtained the ability to understand the concept based on auditorial learning style for students who follow the model of learning mathematics Knisley better than the ability to understand the concept based on visual and kinesthetic learning style

Keywords: Understanding Mathematical Concepts, Knisley Learning Model, Learning Styles

\section{A. PENDAHULUAN}

Pendidikan tidak lepas dari salah satu disiplin ilmu yang erat hubungannya dengan kehidupan sehari-hari yaitu matematika. Matematika sangatlah penting dipelajari, apalagi dalam dunia yang serba canggih ini dan terus bergerak maju. Hampir semua disiplin ilmu menggunakan disiplin ilmu matematika.

Pembelajaran umum matematika menggariskan peserta didik harus mempelajari matematika melalui pemahaman dan aktif membangun pengetahuan baru, pengalaman, dan pengetahuan yang dialami sebelumnya. Selain itu, matematika memiliki konsep struktur dan hubungan-hubungan yang banyak menggunakan simbol-simbol. Simbol-simbol matematika sangat bermanfaat untuk mempermudah cara kerja berpikir, karena simbol-simbol dapat digunakan untuk mengkomunikasikan ide-ide dengan jalan memahami karakteristik matematika (Uno, 2012).

Mengingat matematika memiliki beberapa bagian yang satu sama lain saling berhubungan, maka yang penting dalam belajar matematika adalah bagaimana kemampuan seseorang dalam memahami konsep matematika. Kenyataan di lapangan, kebanyakan siswa hanya menghafal rumus yang sudah ada dan kurang mampu mengaitkan asal mula rumus tersebut dengan konsep yang dimiliki. 
Pengukuran Kemampuan Pemahaman Konsep....(Irsyadatul Mahmudah)

Kemampuan pemahaman matematis adalah kemampuan menyerap dan memahami ide-ide matematika (dalam Lestari \& Yudhanegara, 2015:81). Dalam penelitian ini menggunakan indikator kemampuan pemahaman konsep yang dikemukakan oleh Pollatsek (dalam Hendriana dkk, 2014:4) sebagai berikut: (a) pemahaman komputasional, yaitu mampu menerapkan rumus dalam perhitungan sederhana dan mengerjakan perhitungan secara algoritmik, dan (b) pemahaman fungsional, yaitu mampu mengaitkan satu konsep/prinsip dengan konsep/prinsip lainnya dan menyadari proses yang dikerjakannya.

Mencermati proses pembelajaran matematika di tingkat SMP/MTs masih banyak yang menggunakan model pembelajaran konvensional. Pada umumnya guru dalam kegiatan pembelajaran dimulai dengan menerangkan materi, memberikan contoh cara menyelesaikan soal, dan memberi tugas rumah.

Untuk mengatasi persoalan di atas, peneliti menawarkan kepada guru agar menggunakan model pembelajaran yang dapat menarik siswa dalam belajar matematika dan meningkatkan kemampuan pemahaman konsep matematika siswa. Salah satu model pembelajaran yang tepat yaitu model pembelajaran matematika Knisley (MPMK).

MPMK dikembangkan oleh Dr. Jeff Knisley. Model Pembelajaran Matematika Knisley merupakan model pembelajaran yang dapat diterapkan pada setiap materi matematika. Keunggulan Model Pembelajaran Matematika Knisley terletak pada tahap-tahap pembelajarannya yang terstruktur, dimana pengalaman belajar yang diperoleh siswa akan lebih tahan lama dalam memori karena siswa membangun sendiri pengetahuannya, pada akhirnya akan dapat meningkatkan hasil belajar siswa pada mata pelajaran matematika.

Adapun langkah-langkah dalam melakukan model pembelajaran Knisley adalah sebagai berikut: 
Wahana Didaktika Vol. 16 No.2 Mei 2018 : 131-144

Tabel 1. Langkah-langkah Model Pembelajaran Matematika Knisley

\begin{tabular}{|c|l|l|l|}
\hline No & Tahap & $\begin{array}{c}\text { Hal yang } \\
\text { Dilakukan Guru }\end{array}$ & \multicolumn{1}{|c|}{ Hal yang Dilakukan Siswa } \\
\hline 1 & $\begin{array}{l}\text { Konkrit- } \\
\text { Reflektif }\end{array}$ & $\begin{array}{l}\text { Guru bertindak } \\
\text { sebagai pencerita }\end{array}$ & $\begin{array}{l}\text { Siswa merumuskan konsep baru berdasarkan } \\
\text { konsep yang telah diketahuinya dan belum } \\
\text { dapat membedakan konsep baru dengan } \\
\text { konsep yang telah dikuasainya. }\end{array}$ \\
\hline 2 & $\begin{array}{l}\text { Konkrit- } \\
\text { Aktif }\end{array}$ & $\begin{array}{l}\text { Guru bertindak } \\
\text { Sebagai } \\
\text { pembimbing } \\
\text { dan motivator }\end{array}$ & $\begin{array}{l}\text { Siswa mencoba untuk mengukur, } \\
\text { menggambar, menghitung, dan } \\
\text { membandingkan untuk membedakan konsep } \\
\text { baru dengan konsep lama yang telah } \\
\text { diketahuinyar }\end{array}$ \\
\hline 3 & $\begin{array}{l}\text { Abstrak- } \\
\text { Reflektif }\end{array}$ & $\begin{array}{l}\text { Guru bertindak } \\
\text { Sebagai } \\
\text { narasumber }\end{array}$ & $\begin{array}{l}\text { Siswa menginginkan algoritma dengan } \\
\text { penjelasan yang masukakal, menyelesaikan } \\
\text { masalah dengan suatu logika, melangkah tahap } \\
\text { demi tahap dimulai dengan asumsi awal dan } \\
\text { suatu kesimpulan sebagai logika. }\end{array}$ \\
\hline 4 & $\begin{array}{l}\text { Abstrak- } \\
\text { Aktif }\end{array}$ & $\begin{array}{l}\text { Guru bertindak } \\
\text { Sebagai pelatih }\end{array}$ & $\begin{array}{l}\text { Siswa menyelesaikan masalah dengan konsep } \\
\text { yang telah dibentuk. }\end{array}$ \\
\hline
\end{tabular}

Pada sisi yang lain, jika dilihat dari situasi dan kondisi dari perkembangan pembelajaran siswa, gaya berlajar sangat berpengaruh tehadap kemampuan pemahaman konsep matematika. Tujuan penelitian ini untuk mengetahui ada atau tidaknya perbedaan yang signifikan antara kemampuan pemahaman konsep siswa yang mengikuti model pembelajaran matematika Knisley (MPMK) berdasarkan gaya belajar dengan kemampuan pemahaman konsep siswa yang mengikuti pembelajaran konvensional. Menurut DePorter dan Hernacki (2008) ada tiga tipe belajar yang dikenal (berdasarkan modalitas belajar) yaitu: Visual, Auditorial, dan Kinestetik.

\section{B. METODOLOGI PENELITIAN}

Penelitian ini menggunakan metode penelitian kombinasi (Mixed Methods) dengan Sequential Explanatory Design. Menurut Sugiyono (2016:409) bahwa metode kombinasi model sequential explanatory adalah metode kombinasi yang menggabungkan metode penelitian kuantitatif dan kualitatif secara berurutan dimana pada tahap pertama penelitian menggunakan metode kuantitatif dan pada 
Pengukuran Kemampuan Pemahaman Konsep....(Irsyadatul Mahmudah)

tahap kedua menggunakan metode kualitatif. Penelitian ini dilaksanakan di SMP Islam 01 Batu Tahun Pelajaran 2017/2018 dari tanggal 17 April sampai 16 Mei 2018. Pelaksanaan penelitian dilakukan selama 4 kali pertemuan.

Pada metode penelitian kuantitatif menggunakan jenis Factorial Experimental Design yang terdiri dari dua kelompok penelitian yaitu kelas eksperimen (kelas perlakuan) merupakan kelompok siswa yang menerapkan model pembelajaran matematika Knisley (MPMK) dan kelas kontrol yaitu kelompok siswa yang menerapkan model pembelajaran konvensional.

Populasi dalam penelitian ini adalah seluruh siswa kelas VII semester genap SMP Islam 01 Batu Tahun Pelajaran 2017/2018. Teknik sampling yang digunakan pada penelitian ini adalah simple random sampling, yaitu dengan mengambil dua kelas secara acak tanpa memperhatikan strata yang ada dalam populasi. Sehingga diperoleh kelas VII-A sebagai kelas eksperimen dan kelas VII-B sebagai kelas kontrol yang masing-masing terdiri dari 23 siswa.

Instrumen yang digunakan pada penelitian ini adalah instrumen tes kemampuan pemahaman konsep yang berupa soal-soal uraian yang terdiri dari 4 butir soal dan angket gaya belajar yang berupa pertanyaan sebanyak 30 butir soal . Instrumen tes ini disusun sesuai dengan indikator kemampuan pemahaman konsep menurut Pollatsek dan indikator gaya belajar (DePorter dan Hernacki).

Analisis data dalam penelitian ini untuk penelitian kuantitaf adalah dengan menggunakan uji normalitas, uji homogenitas , uji-t, dan uji two-way ANOVA. Uji normalitas digunakan untuk mengetahui sampel berasal dari populasi yang berdistribusi normal atau tidak. Uji homogenitas sampel digunakan untuk mengetahui varians kedua kelas homogen atau tidak. Sedangkan uji-t digunakan untuk pengujian kesamaan rata-rata. Uji two-way ANOVA digunakan untuk mengetahui ada tidaknya perbedaan kemampuan pemahaman konsep berdasarkan gaya belajar antara siswa yang melalui model pembelajaran matematika Knisley (MPMK) dan siswa yang melalui model pembelajaran konvensional. Sedangkan penelitian kualitatif dengan uji keabsahan data antara data tes kemampuan 
pemahaman konsep dengan data wawancara dan data observasi dengan data wawancara model pembelajaran matematika Knisley.

\section{HASIL DAN PEMBAHASAN}

Berikut hasil deskripsi data kuantitatif diperoleh data pretest dan posttest kemampuan pemahaman konsepsebagai berikut:

Tabel 2 Hasil Pretest Kemampuan Pemahaman Konsep

\begin{tabular}{cccc}
\hline ModelPembelajaran & Mean & Standart Deviation & N \\
\hline MPMK & 30,87 & 8,996 & 23 \\
\hline Konvensional & 30,52 & 8,795 & 23 \\
\hline Jumlah & 61,39 & 17,791 & 46 \\
\hline Rata-rata & 30,70 & 8,8955 & - \\
\hline
\end{tabular}

Tabel 3 Hasil Posttest Kemampuan Pemahaman Konsep Berdasarkan Gaya Belajar

\begin{tabular}{ccccc}
\hline Kelas & Gaya Belajar & Mean & Standart Deviation & N \\
\hline \multirow{3}{*}{ MPMK } & Visual & 78,90 & 7,724 & \\
\cline { 2 - 4 } & Auditorial & 81,63 & 6,479 & \\
\cline { 2 - 4 } & Kinestetik & 63,20 & 9,654 & \\
\hline \multirow{2}{*}{$\begin{array}{c}\text { Konven- } \\
\text { sional }\end{array}$} & Visual & 64,86 & 13,993 & \\
\cline { 2 - 4 } & Auditorial & 74,36 & 10,376 & \multirow{2}{*}{46} \\
\cline { 2 - 4 } & Kinestetik & 61,40 & 10,877 & - \\
\hline \multicolumn{2}{c}{ Jumlah } & 424,4 & 59,103 & \\
\hline \multicolumn{2}{c}{ Rata-rata } & 72,54 & 12,018 &
\end{tabular}

Selanjutnya dilakukan analisis data kuantitatif, data kualitatif, dan gabungan data kuantitatif dan kualitatif sebagai berikut:

\section{Data Kuantatif}

\section{Analisis Data Hasil Pretest Kemampuan Pemahaman Konsep}

a) Uji Normalitas

\section{Tabel 4 Hasil Uji Normalitas Data Pretest}

\begin{tabular}{cccc}
\hline \multirow{2}{*}{ Kelas } & \multicolumn{3}{c}{ Shapiro-Wilk } \\
\cline { 2 - 4 } & Statistic & Df & Sig. \\
\hline Eksperimen &, 960 & 23 &, 469 \\
\hline Kontrol &, 960 & 23 &, 461 \\
\hline
\end{tabular}

Berdasarkan hasil uji normalitas data pretest pada Tabel 4 maka diperoleh nilai Sig $=0,469>0,05$ untuk kelas eksperimen dan nilai Sig $=0,461>0,05$ untuk kelas kontrol. Dengan demikian, $H_{0}$ diterima sehingga data pretest kelas eksperimen dan kelas kontrol berdistribusi normal. 


\section{b) Uji Homogenitas}

\begin{tabular}{cccc}
\multicolumn{4}{c}{ Tabel 5 Hasil Uji Homogenitas } \\
\hline $\begin{array}{c}\text { Levene } \\
\text { Statistic }\end{array}$ & $\mathbf{d f}_{1}$ & $\mathbf{d f}_{2}$ & Sig. \\
\hline $\mathbf{0 , 0 0 5}$ & 1 & 44 & 0,942 \\
\hline
\end{tabular}

Berdasarkan hasil uji homogenitas data pretest pada Tabel 5 maka diperoleh nilai Sig $=0,942>0,05$. Dengan demikian, $H_{0}$ diterima sehingga tidak ada perbedaan varians antara kelas eksperimen dan kelas kontrol atau homogen.

\section{c) Uji Kesamaan Rata-rata}

Tabel 6 Hasil Uji Kesamaan Rata-rata

\begin{tabular}{|c|c|c|c|c|c|}
\hline \multicolumn{3}{|c|}{ Levene's Test for Equality of Variances } & \multicolumn{3}{|c|}{ t-test for Equality of Means } \\
\hline & $F$ & Sig. & $T$ & $d f$ & Sig (2-tailed) \\
\hline $\begin{array}{c}\text { Equal variances } \\
\text { assumed }\end{array}$ & 0,05 & 0,942 & 0,133 & 44 & 0,895 \\
\hline $\begin{array}{l}\text { Equal variances } \\
\text { not assumed }\end{array}$ & & - & 0,133 & 43,977 & 0,895 \\
\hline
\end{tabular}

Berdasarkan hasil uji kesamaan rata-rata Tabel 6maka diperoleh nilai Sig (2-tailed) $=0,895>0,05$. Dengan demikian, ${ }_{0}$ diterima sehingga tidak terdapat perbedaan kemampuan awal antara kelas eksperimen dan kelas kontrol atau kemampuan awal kedua kelas sama.

\section{Analisis Data Hasil Posttest Kemampuan Pemahaman Konsep Berdasarkan Gaya Belajar a) Uji Normalitas}

Tabel 7 Hasil Uji Normalitas Data Posttest

\begin{tabular}{crcc}
\hline \multirow{2}{*}{ Kelas } & \multicolumn{3}{c}{ Shapiro-Wilk } \\
\cline { 2 - 4 } & Statistic & Df & Sig. \\
\hline Eksperimen & 0,932 & 23 & 0,121 \\
\hline Kontrol & 0,931 & 23 & 0,116 \\
\hline
\end{tabular}

Berdasarkan hasil uji normalitas data posttest pada Tabel 7, maka diperoleh nilai Sig $=0,121>0,05$ untuk kelas eksperimen dan nilai Sig $=0,116>0,05$ untuk kelas kontrol. Dengan demikian, $H_{0}$ diterima sehingga data posttest kelas eksperimen dan kelas kontrol berdistribusi normal. 


\section{b) Uji Homogenitas}

Tabel 8 Hasil Uji Homogenitas Data Posttest

\begin{tabular}{cccc}
\hline $\begin{array}{c}\text { Levene } \\
\text { Statistic }\end{array}$ & $\mathbf{d f}_{1}$ & $\mathbf{d f}_{2}$ & Sig. \\
\hline $\mathbf{1 , 9 6 3}$ & 1 & 44 & 0,168 \\
\hline
\end{tabular}

Berdasarkan hasil uji homogenitas data posttest pada Tabel 8, maka diperoleh nilai Sig $=0,168>0,05$. Dengan demikian, $H_{0}$ diterima sehingga tidak ada perbedaan varians antara kelas eksperimen dan kelas kontrol atau homogen.

c) Uji Two-Way ANOVA

Tabel 9 Uji Hipotesis Dua Pihak

\begin{tabular}{|c|c|c|c|c|c|}
\hline Source & $\begin{array}{c}\text { Type III Sum } \\
\text { of Squares }\end{array}$ & Df & $\begin{array}{c}\text { Mean } \\
\text { Square }\end{array}$ & $F$ & $\begin{array}{c}\text { Sig } \\
\cdot\end{array}$ \\
\hline $\begin{array}{c}\text { Model } \\
\text { Pembelajaran }\end{array}$ & 621,6 & 1 & 621,595 & 6,330 & 0,016 \\
\hline Gaya Belajar & 1603,6 & 2 & 801,800 & 8,165 & 0,001 \\
\hline $\begin{array}{c}\text { Model } \\
\text { Pembelajaran * } \\
\text { GayaBelajar }\end{array}$ & 245,83 & 2 & 122,914 & 1,252 & 0,297 \\
\hline
\end{tabular}

Berdasarkan hasil uji hipotesis Tabel 9, maka diperoleh nilai Sig = $0,016<0,05$. Dengan demikian, $H_{0}$ ditolak sehingga terdapat perbedaan kemampuan pemahaman konsep (KPK) pada kelas dengan model pembelajaran matematika Knisley (MPMK) dan yang tidak dengan model pembelajaran matematika Knisley (MPMK) berdasarkan gaya belajar (Gabel). Sedangkan pada baris gaya belajar dengan nilai $\mathrm{Sig}=0,001<0,05$, maka $H_{0}$ ditolak sehingga dapat disimpulkan terdapat perbedaan antara kemampuan pemahaman konsep matematika (KPK) siswa visual, auditorial, dan kinestetik. Adapun pada baris faktor model pembelajaran*gaya belajar dengan nilai Sig $=0,297>0,05$, maka $H_{0}$ diterima sehingga dapat disimpulkan tidak terdapat interaksi faktor model pembelajaran dan faktor gaya belajar terhadap kemampuan pemahaman konsep (KPK). 
Pengukuran Kemampuan Pemahaman Konsep....(Irsyadatul Mahmudah)

\section{d) Uji Hipotesis (Uji-t satu pihak (Gabel Visual))}

Berdasarkan uji hipotesis atau uji-t yang didapatkan dengan membandingkan antara $t_{\text {kixtung }}$ dan $t_{\text {tabel }}$ diperoleh nilai $t_{\text {kitung }}=3,2084095$ dan $t_{\text {tabel }}=1,76131$ dengan $d k=15$. Karena $\quad t_{\text {kitung }}>-t_{\text {tabel }} \quad$ atau 3,2084095 >-1,76131 Dengan demikian, $H_{0}$ ditolak sehingga kemampuan pemecahan masalah (KPK) berdasarkan gaya belajar (Gabel) visual pada kelas eksperimen (menggunakan pembelajaran “Batas Mol MPMK”) lebih baik dengan kelas kontrol (menggunakan model pembelajaran konvensional).

\section{e) Uji Hipotesis (Uji-t satu pihak (Gabel Auditorial))}

Berdasarkan uji hipotesis atau uji-t yang didapatkan dengan membandingkan antara $t_{\text {hitung }}$ dan $t_{\text {tabel }}$ diperoleh nilai $t_{\text {kitung }}=3,750210126$ dan $t_{\text {tabel }}=1,73961$ dengan $d k=17$. Karena $\quad t_{\text {kitung }}>-t_{\text {tabel }} \quad$ atau 3,75021012558>-1,73961. Dengan demikian, $H_{0}$ ditolak sehingga kemampuan pemecahan masalah (KPK) berdasarkan gaya belajar (Gabel) auditorial pada kelas eksperimen (menggunakan model pembelajaran matematika Knisley lebih baik dengan kelas kontrol (menggunakan model pembelajaran konvensional).

\section{f) Uji Hipotesis (Uji-t satu pihak (Gabel Kinestetik))}

Berdasarkan uji hipotesis atau uji-t yang didapatkan dengan membandingkan antara $t_{\text {hitung }}$ dan $t_{\text {tabel }}$ diperoleh nilai $t_{\text {kitung }}=0,27044291$ dan $t_{\text {tabel }}=1,85955$ dengan $d k=8$. Karena $t_{\text {Ritung }}>-t_{\text {tabel }}$ atau 0,27044291 >-1,85955 Dengan demikian, $H_{0}$ ditolak sehingga kemampuan pemecahan masalah (KPK) berdasarkan gaya belajar (Gabel) kinestetik pada kelas eksperimen (menggunakan model pembelajaran matematika Knisley) lebih baik dengan kelas kontrol (menggunakan model pembelajaran konvensional). 
Wahana Didaktika Vol. 16 No.2 Mei 2018 : 131-144

\section{g) Uji Hipotesis (Uji-t satu pihak (Gabel Visual-Auditorial))}

Berdasarkan uji hipotesis atau uji-t yang didapatkan dengan

membandingkan antara $t_{\text {hitung }}$ dan $t_{\text {tabel }}$ diperoleh nilai $t_{\text {hitung }}=1,66888229$ dan $t_{\text {tabel }}=-1,85955$ dengan $d k=16$. Karena $t_{\text {hitung }}>-t_{\text {tabel }}$ atau $1,66888229>-1,85955$. Dengan demikian, $H_{0}$ ditolak sehingga kemampuan pemecahan masalah (KPK) berdasarkan gaya belajar (Gabel) auditorial lebih baik dibandingkan kemampuan pemecahan masalah (KPK) berdasarkan gaya belajar (Gabel) visual pada kelas eksperimen (menggunakan model pembelajaran matematika Knisley).

\section{h) Uji Hipotesis (Uji-t satu pihak (Gabel Auditorial-Kinestetik))}

Berdasarkan uji hipotesis atau uji-t yang didapatkan dengan membandingkan antara $t_{\text {hitung }}$ dan $t_{\text {tabel }}$ diperoleh nilai $t_{\text {hitung }}=7,41741168$ dan $t_{\text {tabel }}=1,77093$ dengan $d k=13$. Karena $t_{\text {hitung }}>-t_{\text {tabel }}$ atau 7,41741168 $>-1,77093$. Dengan demikian, $H_{0}$ ditolak sehingga kemampuan pemecahan masalah (KPK) berdasarkan gaya belajar (Gabel) auditorial lebih baik dibandingkan kemampuan pemecahan masalah (KPK) berdasarkan gaya belajar (Gabel) kinestetik pada kelas eksperimen (menggunakan model pembelajaran matematika Knisley).

\section{DATA KUANTITATIF}

\section{Analisis Data Hasil Posttest Kemampuan Pemahaman KonsepBerdasarkan Gaya Belajar dan Data Wawancara}

Tabel 10 Hasil Perbandingan Antara Data Posttest dan Data Wawancara

\begin{tabular}{|c|c|c|c|c|}
\hline & Kelas & Visual & Auditorial & Kinestetik \\
\hline \multirow{2}{*}{ HasilPosttes } & Eksperimen & $78,90 \%$ & $81,63 \%$ & $63,20 \%$. \\
\hline & Kontrol & $64,86 \%$ & $74,36 \%$ & $61,40 \%$ \\
\hline \multirow{2}{*}{ HasilWawancara } & Eksperimen & $\begin{array}{c}75 \% \\
\text { (memenuhi } 3 \\
\text { indikatorKPK) }\end{array}$ & $\begin{array}{c}100 \% \\
\text { (memenuhi } \\
\text { 4indikatorKPK) }\end{array}$ & $\begin{array}{c}75 \% \\
\text { (memenuhi } 3 \\
\text { indikatorKPK) }\end{array}$ \\
\hline & Kontrol & $\begin{array}{c}50 \% \\
\text { (memenuhi } \\
\text { 2indikatorKPK) }\end{array}$ & $\begin{array}{c}75 \% \\
\text { (memenuhi } 3 \\
\text { indikatorKPK) }\end{array}$ & $\begin{array}{c}50 \% \\
\text { (memenuhi } \\
\text { 2indikatorKPK) }\end{array}$ \\
\hline
\end{tabular}


Berdasarkan Tabel 10 bahwa kemampuan pemahaman konsep (KPK) berdasarkan gaya belajar dengan model pembelajaran matematika Knisley lebih baik daripada kemampuan pemahaman konsep (KPK) berdasarkan gaya belajar dengan pembelajaran konvensional yang dapat dilihat dari persentase nilai ratarata dan juga pada kelas eksperimen menunjukkan bahwa kemampuan pemahaman konsep (KPK) berdasarkan gaya belajar (Gabel) auditorial lebih baik daripada kemampuan pemahaman konsep (KPK) berdasarkan gaya belajar (Gabel) visual dan kinestetik.

\section{Analisis Data Hasil Observasi}

\begin{tabular}{cccc}
\hline \multirow{2}{*}{ Kelas } & \multicolumn{2}{c}{ Data Observasi } & \\
\cline { 2 - 3 } Ekperimen & $\begin{array}{c}\text { Kegiatan } \\
\text { Guru }\end{array}$ & $\begin{array}{c}\text { Kegiatan } \\
\text { Siswa }\end{array}$ & Data Wawancara \\
\hline \multirow{2}{*}{ Kontrol } & $\begin{array}{c}82,05 \% \\
\text { (Sangat } \\
\text { baik) }\end{array}$ & $\begin{array}{c}80,25 \% \\
\text { (Sangat } \\
\text { baik) }\end{array}$ & $\begin{array}{c}\text { (Subjek menyatakan bahwa merasa } \\
\text { senang mengikuti pembelajaran } \\
\text { matematika Knisley) }\end{array}$ \\
\hline $\begin{array}{c}87,70 \% \\
\text { (Sangat } \\
\text { baik) }\end{array}$ & $\begin{array}{c}84,70 \% \\
\text { (Sangat } \\
\text { baik) }\end{array}$ & $\begin{array}{c}\text { (Subjek menyatakan bahwa merasa } \\
\text { senang mengikuti pembelajaran } \\
\text { konvensional) }\end{array}$ \\
\hline
\end{tabular}

Berdasarkan Tabel 11 diperoleh bahwa data observasi kegiatan guru dan siswa terlaksana dengan sangat baik, hal ini diperkuat dengan data wawancara yang menunjukkan bahwa siswa merasa senang dengan model pembelajaran matematika Knisley.

\section{GABUNGAN DATA KUANTITATIF DAN DATA KUALITATIF}

Analisis data kuantitatif dan kualitatif dapat dilakukan dengan cara membandingkan hasil penelitian kuantitatif dengan hasil penelitian kualitatif yang diperoleh sebagai berikut:

(1) Kemampuan pemahaman konsep (KPK) berdasarkan gaya belajar (Gabel) visual pada kelas eksperimen menggunakan model pembelajaran matematika Knisley (MPMK) lebih baik dibandingkan dengan kelas kontrol menggunakan pembelajaran konvensional. 
(2) Kemampuan pemahaman konsep (KPK) berdasarkan gaya belajar (Gabel) auditorial pada kelas eksperimen menggunakan model pembelajaran matematika Knisley (MPMK) lebih baik dibandingkan dengan kelas kontrol menggunakan pembelajaran konvensional.

(3) Kemampuan pemahaman konsep (KPK) berdasarkan gaya belajar (Gabel) kinestetik pada kelas eksperimen menggunakan model pembelajaran matematika Knisley (MPMK) lebih baik dibandingkan dengan kelas kontrol menggunakan pembelajaran konvensional.

(4) Kemampuan pemahaman konsep (KPK) berdasarkan gaya belajar (Gabel) auditorial pada kelas eksperimen menggunakan model pembelajaran matematika Knisley (MPMK) lebih baik dibandingkan dengan kemampuan pemahaman konsep (KPK) berdasarkan gaya belajar (Gabel) visual.

(5) Kemampuan pemahaman konsep (KPK) berdasarkan gaya belajar (Gabel) auditorial pada kelas eksperimen menggunakan model pembelajaran matematika Knisley (MPMK) lebih baik dibandingkan dengan kemampuan pemahaman konsep (KPK) berdasarkan gaya belajar (Gabel) kinestetik.

(6) Pada kelas eksperimen siswa dengan gaya belajar (Gabel) visual dapat memenuhi 3 indikator kemampuan pemahaman konsep (KPK).

(7) Pada kelas eksperimen siswa dengan gaya belajar (Gabel) auditorial dapat memenuhi 4 indikator kemampuan pemahaman konsep (KPK).

(8) Pada kelas eksperimen siswa dengan gaya belajar (Gabel) auditorial dapat memenuhi 3 indikator kemampuan pemahaman konsep (KPK).

Sehingga dapat disimpulkan bahwa hasil penelitian kuantitatif menunjukkan bahwa terdapat perbedaan kemampuan pemahaman konsep (KPK) berdasarkan gaya belajar (Gabel) antara kelas eksperimen (menggunakan model pembelajaran matematika Knisley (MPMK)) dan kelas kontrol (menggunakan model pembelajaran konvensional). Penelitian kualitatif diperoleh kemampuan pemahaman konsep (KPK) berdasarkan gaya belajar (Gabel) pada kelas eksperimen (menggunakan model pembelajaran matematika Knisley (MPMK)) lebih baik dibandingkan kelas kontrol (menggunakan model pembelajaran 
Pengukuran Kemampuan Pemahaman Konsep....(Irsyadatul Mahmudah)

konvensional), dan kemampuan pemahaman konsep (KPK) berdasarkan gaya belajar (Gabel) auditorial pada kelas eksperimen (menggunakan model pembelajaran matematika Knisley (MPMK)) lebih baik dibandingkan kelas kontrol (menggunakan model pembelajaran konvensional).

Hasil tersebut diperoleh dengan menerapkan model pembelajaran matematika Knisley (MPMK). Dalam penerapan pembelajaran tersebut peserta didik terlihat begitu aktif. Setiap tahap dalam pembelajaran memberikan kesempatan untuk meningkatkan kemampuan pemahaman konsep (KPK). Hal ini sesuai dengan apa yang disampaikan oleh Rosa (2017:46) bahwa tahapan dari Model Pembelajaran Matematika Knisley mendukung pengembangan kemampuan pemahaman matematis siswa karena siswa akan lebih berperan aktif dalam proses pembelajaran. Ada 4 tahap dalam Model Pembelajaran Matematika Knisley (MPMK) itu adalah konkret-reflektif (guru sebagai pencerita), konkretaktif (guru sebagai pembimbing dan motivator), abstrakreflektif (guru sebagai narasumber), dan abstrak-aktif (guru sebagai pelatih).

Oleh karena itu, dapat disimpulkan bahwa penerapan model pembelajaran matematika Knisley (MPMK) terbukti dapat meningkatkan kemampuan pemahaman konsep (KPK) pada kelas eksperimen berdasarkan gaya belajar (Gabel) siswa.

\section{SIMPULAN}

Berdasarkan hasil penelitian dan pembahasan dapat disimpulkan bahwa terdapat perbedaan antara kemampuan pemahaman konsep (KPK) yang mengikutimodel pembelajaran matematika Knisley (MPMK) berdasarkan gaya belajar (Gabel) dan kemampuan pemahaman konsep (KPK) yang mengikuti pembelajaran konvensional, kemampuan pemahaman konsep (KPK) yang mengikutimodel pembelajaran matematika Knisley (MPMK) berdasarkan gaya belajar (Gabel) lebih baik dibandingkan kemampuan pemahaman konsep (KPK) yang mengikuti pembelajaran konvensional, serta kemampuan pemahaman konsep (KPK) berdasarkan gaya belajar (Gabel) auditorial lebih baik 
dibandingkan gaya belajar (Gabel) visual dan kinestetik yang mengikuti pembelajaran “Batas Mol MPMK”.

Penerapan model pembelajaran matematika Knisley (MPMK) terhadap kemampuan pemahaman konsep (KPK) siswa memberikandampak yang positif. Hal ini dikarenakan pembelajaran konvensional yang kurang aktif dan siswa cenderung hanya mengikuti langkah-langkah yang diberikan oleh gurunya, dan pada akhirnya akan sangat berpengaruh pada kemampuan pemahaman matematis siswa. Sehingga kemampuan pemahaman konsep (KPK) siswa yang mengikuti model pembelajaran matematika Knisley (MPMK) lebih baik dibandingkan siswa yang mengikuti pembelajaran konvensional, serta kemampuan pemahaman konsep (KPK) berdasarkan gaya belajar (Gabel) auditorial lebih baik dibandingkan gaya belajar (Gabel) visual dan kinestetik pada kelas yang menggunakan model pembelajaran matematika Knisley (MPMK). Sehinggga kemampuan pemahaman konsep (KPK) berdasarkan gaya belajar (Gabel) auditorial meningkat dengan menggunakan model pembelajaran matematika Knisley (MPMK).

\section{DAFTAR PUSTAKA}

Deporter, B. \& Mike H. 2008. Quantum Learning. Membiasakan Belajar Nyaman dan Menyenangkan. Bandung: Kaifa.

Hendriana, H, Rohaeti E. E, \& Sumarmo, U. 2014. Hard Skills dan Soft Skills Matematika Siswa. Bandung: Refika Aditama.

Lestari, K. E dan Yudhanegara, M. Ridwan. 2015. Penelitian Pendidikan Matematika. Bandung: PT. Refika Aditama.

Sugiyono. 2016. Metode Penelitian Kombinasi (Mixed Methods). Bandung: Alfabeta.

Uno, H.B. 2012. Model Pembelajaran Menciptakan Proses Belajar Mengajar yang Kreatif dan Efektif. Jakarta: PT. Bumi Aksara.

Rosa, Elvira. 2017. "Pengaruh Penerapan Model Pembelajaran Matematika Knisley (MPMK) Menggunakan Media Petak Warnawarni terhadap Kemampuan Pemahaman Matematis Siswa dalam Pembelajaran Segitiga di Kelas VII MTs. Putra-Putri Simo". Jurnal Inovasi Pendidikan dan Pembelajaran Matematika. Vol 3 (1): 43-52. 